Journal of Agriculture and Social Research (JASR) Vol. 8, No. 2, 2008

\title{
EFFECT OF SALES PROMOTION ON THE VOLUME OF SALES OF AGRO- PRODUCT (ROYCO)
}

\author{
*IFEANYI-OBI C.C, **J. LEMCHI AND *B.I. ISIFE \\ *Department of Agricultural Economics and Extension, Rivers State University of Science \\ and Technology, Port Harcourt. \\ **Department of Agricultural Economics, Federal University of Technology, Owerri, \\ Nigeria
}

\begin{abstract}
Increase demand of agricultural products has been viewed as a means of inducing greater production in the agricultural sector. Therefore, efficient marketing of Agro-products will result to increase in demand of farm products and this will serve as a great incentive to increase production in the Agricultural sector. The main objective of this study is to evaluate the effect of sales promotion on the volume of sales of Royco in Onitsha Urban city of Anambra State for the years 1998 and 1999. Data for the study was collected from 40 respondents $(20$ staff of UniLever Nig. Plc, producers of Royco and 20 Distributors of Royco) who were selected based on purposive sample technique. Also data from the company's sales record for the 1998 and 1999 sales promotion period was also used. These data were analyzed using simple statistical tools such as, percentages, tables, charts/graphs. Chi-square was used to test the hypothesis at 0.95 significant level. Results from the findings of this research established a positive relationship between sales promotion and sales volume leading to rejection of null hypothesis. That is, it was established that effective sales promotion of Royco induces greater sales of Royco, which in turn results to greater demand of Agro-Products used in the production of Royco. Necessary policy recommendations were made on how to improve the quality and effectiveness of sales promotion.
\end{abstract}

Key words: effects, sales promotion, volume of sales, Royco seasoning.

\section{INTRODUCTION}

Agri-business can be defined as the sum total of all economic activities involved in the production, processing and distribution of food and fibre. This could be perceived as consisting of primary tri-aggregate namely: farm supply (backward linkage industries), farm production (actual farming process or actual production process), food and fibre processing and distribution (forward linkage industries). Farm production is known as the basic source of raw materials to Agro- industries such as Unilever Nigeria Plc. Therefore efficient marketing of Agro-products will result to increase in demand of farm produce and this will serve as a great incentive to increase production in the agricultural section. And for this increase to come about there must be an efficient marketing system in the Agro-industries which will now stimulate more production consequently more demand of farm produce.

Marketing has been a very important sector in any organization, industry or economy. Many authors identify it as the revenue generating activity in any organization (Agbonifoh, Ogwo and Nnolim, (1998); Achumba and Osuagwu (1994). Therefore for an organization to be efficient the marketing sector must be efficient. The marketing department initiates research and development to access and meet customers want and needs. The challenge that faces marketing is to generate revenue and at the same time satisfy consumers want at a profit (Uturu, 1998). The marketing sector in trying to face this challenge employs a lot of promotional activities to help in informing, persuading and reminding consumers about the company's products or goods. These promotional activities include advertising, personal selling, sales promotion, public relations and publicity. Advertising and personal selling initially have been the two main 


\section{Journal of Agriculture and Social Research (JASR) Vol. 8, No. 2, 2008}

promotional tools used by many organizations but recently, it has been observed that company's expenditure for sales promotion has increased more rapidly than outlays for advertising and personal selling. This shows that sales promotion has grown in importance as an important element of the promotional mix. This increase in the use of sales promotion as a marketing strategy can be attributed to the fact that sales promotion devices are often the only promotional materials at the point of purchase and as such commands a great deal of influence on the consumers decision. It has been found out that the impact of adverts and other promotional tools usually wear-off before the very important consumer purchase decisions are made(Buskirik and Buskirk 1992), therefore a marketing strategy that will inform, remind or otherwise stimulate the buyer at the point of purchase (e.g. sales promotion) has been identified as a veritable and strong promotional tool.

Due to the increase acceptance of sales promotion by firms as a very important element of the promotional mix and its expenditure also being on the rise, it has become very import to examine whether sales promotion is actually making any impact on the volume of sales. This paper specifically evaluates the effect of sales promotion on the volume of sales of royco (a product of Unilever Nig Plc). This paper will also examine the types and nature of sales promotion available in the company.

\section{Hypothesis of the Study}

The null hypothesis states that there is no significant relationship between sales promotion and volume of sales.

\section{METHODOLOGY}

This study was conducted in Onitsha urban city in Anambra state. The period examined were 1998 and 1999. Onitsha urban city was chosen for this study because it has the highest sales volume in the Eastern zone of the country (company's sales record, 1999). Selection of sample (respondents) was based on purposive sample technique. A total number of twenty (20) staff of Unilever Nig Plc and twenty (20) distributors who engage in retail selling were chosen. This is because they directly come in contact with the consumers and as such were in a better position to answer the research questions adequately. Data was collected from both primary and secondary sources. The primary data were gotten from dealers/distributors and staff using questionnaire administered to them. The secondary data came from the company's sales record, publications and annual sales reports for the years 1998 and 1999. The data collected was analyzed by means of simple statistical tools such as mean, percentages, tables/charts and graphs. Chi-square analysis was used for analysis of relationship between variables of the study.

\section{RESULTS AND DISCUSION}

Out of the 20 staff of LBN interviewed, 13 are male while 7 of them are female. This could be as a result of the nature of the job which involves a lot of traveling and other hectic activities which the female may not likely be involved. On the part of the distributors, 8 are male and 12 female. A relatively high percentage of females in the distribution of the product can be attributed to the item being a food condiment which is often dominated by women.

Out of the 20 staff of LBN interviewed, 6 are married while 14 are single. This was said to be as a result of the nature of the job which is time consuming and as such need people who have less responsibilities. 
Journal of Agriculture and Social Research (JASR) Vol. 8, No. 2, 2008

Level of Education

Table 1: Percentage distribution of respondents by Level of Education

\begin{tabular}{l|l|l|l|l}
\hline Level of Education & \multicolumn{2}{l|}{ No of respondents } & \multicolumn{2}{l}{$\%$ of respondents } \\
& Staff & Dealers & Staff & Dealers \\
& & & & \\
\hline OND & 11 & 4 & 28 & 10 \\
HND & 3 & 1 & 8 & 3 \\
B. Sc. & 3 & - & 8 & - \\
GCE/SSCE & 3 & 15 & 8 & 38 \\
& & & & \\
\hline TOTAL & 20 & 20 & 50 & 50 \\
\hline
\end{tabular}

Table 1 show that the dealers are relatively educated. This facilitated the collection of data for this study since most of them understand the need for record keeping and as such keep records of past sales promotion activities carried out. Their relatively high level of education helped in collecting the necessary information through interview as most of them can explain the details of any promotional tool used by the company. On the side of the staff, the table above shows that they are also literate and this enabled them to carry out their jobs effectively.

Sales promotion tools used by Unilever Nig Plc.

The promotional tools identified by the respondents which are used by Unilever Nig Plc include; free sample, premium, Discounts, Contests, coupons, House to house promotion, market storming and open market display. From the number of promotional tools listed above, it can be said that Unilever Nig Plc uses a lot of promotional tools to achieve their sales promotion drive.

Relative importance of the Sales Promotion Tools.

Table 2 Percentage distribution of respondents by types of promotional tools used in the order of their relative importance.

\begin{tabular}{l|l|l|l|l}
\hline Promo Tools & \multicolumn{2}{l|}{ No of respondents } & \multicolumn{2}{l}{$\%$ of respondents } \\
& Staff & Dealers & Staff & Dealers \\
\hline Free Sample & 9 & 10 & 23 & 25 \\
Premium & 6 & 6 & 15 & 15 \\
Discounts & 5 & 4 & 13 & 10 \\
Contests & - & - & - & - \\
Coupons & - & - & - & - \\
\hline TOTAL & & & & \\
\hline
\end{tabular}

Table 2 shows that some of the sales promotion tools were more useful than others. For instance, free sample recorded the highest response. This could be as a result of customer's great affinity towards free items given at the point of sale or purchase than any other type of sales promotion.

Relative Importance of Sales Promotion in increasing the volume of sales 


\section{Journal of Agriculture and Social Research (JASR) Vol. 8, No. 2, 2008}

In trying to find out whether sales promotion increase sales volume, a $100 \%$ positive response was gotten. This is a strong indication that sales promotion help to increase the sales volume of Royco.

\section{Sales promotion effectiveness in achieving the target sales of Royco.}

This question was answered by only the staff of Unilever Nig Plc due to the fact that the dealers/distributors most times do not know the exact target of the company's promotional activity. Out of 20 staff interviewed, $60 \%$ were of the opinion that sales promotion helped to achieve target sales while the rest indicated a negative answer.

\section{Frequency of Sales Promotion in Unilever Nig Plc for Royco}

Out of the 5 time schedule listed in questionnaire (monthly, quarterly, semi-annually, annually and once in 2 years) all the respondents answered that sales promotion was carried out annually for Royco.

\section{The main uses/benefits of sales promotion to Unilever Nig Plc}

The main advantages derive from sales promotion according to the respondents includes;
a). To identify and attract new customers
b). To introduce a new product
c). To increase the total number of users for an established product/brand.
d). To increase/encourage greater usage among current customers
e). To educate customers regarding product improvement.

From the above listed uses/benefits, it can be said that Unilever Nig Plc derive numerous advantages from its sales promotional activities.

\section{Suggestions for improvement of sales promotion}

Suggestions made by the respondents for improving sales promotion include:

a). Unilever Nig Plc should diversify the packaging of their product, that is Royco to make it more appealing to the thirst of the customers. It can come in form of different grams. This will also make the product affordable by different people.

b) More of free gifts should be encouraged as customers respond well to it

c). More attractive wraps should be used in packaging their product.

d). Sales promotion activity should be done more than once in a year.

e). Unilever Nig Plc should create avenue for customers to express their minds or feelings concerning their products and their sales promotional activities.

f). Redemption of free samples or discounts won should be made easier, this can be done by opening up many redemption centers as well as diversifying their locations.

g). Unilever Nig Plc should educate its distributors on the need for sincerity and the importance of not removing any free gift attach to a product.

\section{Effects of Sales Promotion on Sales Volume}

Data of sales volume before, during and after promotion for 1998 and 1999 promotion were compared and analyzed using the chi-square. 
Journal of Agriculture and Social Research (JASR) Vol. 8, No. 2, 2008

Table 3: Sales volume before, during and after sales promotion for period under review, April - June 1998

\begin{tabular}{|l|l|l|l|l|}
\hline S/No & $\begin{array}{l}\text { Name of outlet/ } \\
\text { Customer }\end{array}$ & $\begin{array}{l}\text { Sales Volume of 3 } \\
\text { months before } \\
\text { promotion } \\
\text { (cartons) }\end{array}$ & $\begin{array}{l}\text { Sales Volume of } \\
\text { 3 months during } \\
\text { promotion. } \\
\text { (carton) }\end{array}$ & $\begin{array}{l}\text { Sales Volume of } \\
\text { month after } \\
\text { promotion } \\
\text { (cartons) }\end{array}$ \\
\hline & & & \\
1. & A. A. \& Sons Ltd & 800 & 2000 & 2500 \\
2. & Pa Chike Ventures & 400 & 700 & 800 \\
3. & Egwuonwu Ent. & 150 & 300 & 360 \\
4. & Igwe Stores & 600 & 900 & 903 \\
5. & Jackson Ent. & 250 & 800 & 900 \\
6. & Ejinkeonye Store & 200 & 800 & 1000 \\
7. & Galaxy Stores & 200 & 400 & 506 \\
8. & Goddy Stores & 100 & 500 & 506 \\
9. & Obioma Stores & 40 & 65 & 72 \\
10. & Agans Ventures & 30 & 40 & 52 \\
\hline
\end{tabular}

Source: 1998 Company's Sales record

Table 4: Sales Volume before, during and after sales promotion for the period under review, April - June 1999

\begin{tabular}{|l|l|l|l|l|}
\hline S/No & $\begin{array}{l}\text { Name of outlet/ } \\
\text { Customer }\end{array}$ & $\begin{array}{l}\text { Sales Volume of 3 } \\
\text { months before } \\
\text { promotion } \\
\text { (cartons) }\end{array}$ & $\begin{array}{l}\text { Sales Volume of } \\
\text { 3 month during } \\
\text { promotion. } \\
\text { (carton) }\end{array}$ & $\begin{array}{l}\text { Sales Volume of } \\
\text { months after } \\
\text { promotion } \\
\text { (cartons) }\end{array}$ \\
\hline & & & \\
1. & Obitex stores & 1000 & 1400 & 1600 \\
2. & Adionyemma Stores & 1320 & 1500 & 1560 \\
3. & Chidex Venture & 1150 & 1350 & 1550 \\
4. & Omega \& Sons Ltd & 950 & 1300 & 1500 \\
5. & Mrs. Nzegwu & 650 & 700 & 880 \\
6. & Peace Trading Stores & 500 & 700 & 850 \\
7. & Rose Stores & 400 & 5500 & 600 \\
8. & Goodway Stores & 900 & 1000 & 1050 \\
9. & Regina Udo & 350 & 415 & 460 \\
10. & Madam Uju & 400 & 600 & 700 \\
\hline
\end{tabular}

Source: 1998 Company's Sales Record

From Tables 3 and 4 showing the two periods under review, it is obvious that sales promotion has constantly contributed to increase in sales volume. In the 1998 period, sales volume increased from 2770 cartons to 6505 cartons during promotion representing a sales volume increase of $137 \%$. Also sales after promotion increased by 996 cartons, this is still an appreciable increase. In the 1999 period, sales volume increase from 7620 cartons to 9515 cartons during promotion representing an increase of $25 \%$. Sales after promotion also increased moderately. On the average percentage sales volume before, during and after stood at $17 \%, 39 \%$ and $45 \%$ for 1998 and $27 \%, 34 \%$ and $39 \%$ for 1999 . From figures 1 and 2, sales promotion can be said to have contributed about $80 \%$ of the sales volume increase. From this analysis, it is evident that Unilever Nig Plc has been using sales promotion to increase the volume of sales which is an incentive to increase production and at the same time increase in the demand of raw material (Farm Products). 


\section{Journal of Agriculture and Social Research (JASR) Vol. 8, No. 2, 2008}

\section{Testing the Hypothesis}

The hypothesis is as follows:

Ho; there is no significant relationship between sales promotion and volume of sales. The two periods being compared and analyzed are 1998 and 1999 sales promotion period. The hypothesis is tested using chi-square formula.

$\mathrm{X}^{2}$ cal $=\Sigma(0-\mathrm{E}) 2$

Where $\mathrm{X}^{2} \mathrm{cal}=\mathrm{E}$ Chi-square calculated

$\mathrm{O}=$ Observed Sales Volume

$\mathrm{E} \quad=\quad$ Expected Sales Volume

For the 1998 period:

$\mathrm{X}$ cal value is 360.16 while $\mathrm{x}^{2}$ tab at degrees of freedom 18 and 0.95 significant level is 28.9

For the 1999 period:

$\mathrm{X}$ cal value is 96.4 while $\mathrm{x}$ tab at degrees of freedom 18 and 0.95 significant level is 28.9 .

\section{Decision rule:}

If $\mathrm{x}^{2} \mathrm{cal}>\mathrm{x}^{2}$ tab reject $\mathrm{H}_{0}$, if otherwise accept $\mathrm{H}_{1}$, since $\mathrm{x}$ cal is greater than $\mathrm{x}$ tab for the two years (1998 and 1999), the null hypothesis is therefore rejected and the second hypothesis (i.e. alternative hypothesis) which states that there is a significant relationship between sales promotion and volumes of sales is accepted. This implies that sales promotion has a significant effect on the volume of sales, either positive or negative. But from the data gathered from the respondents, it can be proved that the effect of sales promotion on volume of sales is a positive one.

\section{CONCLUSION AND RECOMMENDATIONS}

The purpose of this study is to evaluate the effects of sales promotion on the volume of sales of royco a product of unilever Nig plc for the period 1998 and 1999. The results obtained showed that there is statistically significant relationship between sales promotion and volume of sales of Royco. It was established that about $70 \%$ to $80 \%$ increase in sales in sales volume of royco was achieved by sales promotion, it was shown that a considerable increase in sales volume in always achieved. From the above explanation it can be seen that sales promotion in Royco induces greater sales which results in increase production consequently increase in demand of raw material (Farm products). Therefore, improving sales promotion of Agro-products is an indirect way of improving or encourages more production in farm products. It is therefore recommended that Agro-industries should employ sales promotional activities in order to boost their sales thereby increasing demand of farm products. Also suggestion on how to improve sales promotion given by the respondents should be applied in conducting sales promotion in order to have successful and profitable sales promotion.

\section{REFERENCES}

Achumba I.C. and Osuagwu, L.C. (1994); Marketing; Fundamentals and Practice, Mukugamu Nig. Company, Lagos.

Agbonifoh, B.A., Ogwo, O.E. and Nnolim, D.A, (1998): Marketing in Nigeria. Afritowers Publishers Ltd.

Buskirik, R.H and Buskirik, B.D, (1990): Selling Mc. Graw-Hill International Editions

Lever Brothers Nig. PLC: Annual Sales Report (Several)

Uturu, C.O. (1998): Marketing Communications. Baset Printing and Publishing Ltd. Enugu. 